Available online: https://journals.researchsynergypress.com/index.php/ijebce/

International Journal of Entrepreneurship, Business and Creative Economy (IJEBCE)

ISSN 2775-3085 (Online) | 2775-3107 (Print)

Volume 2 Number 1 (2022): 1-13

\title{
Bank's Digitalization and Financial Performance during Pandemic in Indonesia
}

\author{
Najwa Khairina ${ }^{1}$ \\ ${ }^{1}$ Economics Development Program, Faculty of Economics and Business, Syarif Hidayatullah State \\ Islamic University, Indonesia
}

\begin{abstract}
The pandemic-led recession has made a downturn in the banking industry's performance. Digitalization is seen as a good strategy to support banks' business operations during the pandemicled recession. This paper focus on how the banking and financial industry maintained their performance during the covid-19 led recessions through digitalization. I use descriptive statistics approach and regression analysis to analyze how digital transformation help to maintain business performance during a pandemic. In addition, I use regression analysis to estimate the effect of a pandemic on banks' financial performance and how digital transactions may help to maintain banks' performance. The regression estimation result shows that pandemic conditions associated with 0.177 points decrease in ROA while digital infrastructure may not have relations with banks' ROA. Further, the volume of digital transactions is associated with the increase of bank's return on asset (ROA) as much as $10 \%$. These results imply that even though pandemics have negative impacts on banks' performance, empirical evidence shows that digital transactions have helped the banking industry to maintain its profit during the pandemic.
\end{abstract}

Keywords: banking; finance, pandemic-led recession; business performance

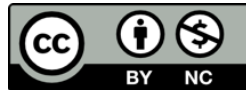

This is an open access article under the CC-BY-NC license.

\section{INTRODUCTION}

The announcement of the first covid-19 case in Indonesia was publicized in early March 2020, and it marks the start of economic downfall. The vast spread of covid-19 has urged the government to restrict social distancing, which resulted in a significant drop in demand and consumption (Craven et al., 2020). GDP growth in the second quarter of 2020 falls to $-5.3 \%$ year on year; however, after the government revoked the regulation of large-scale social restrictions, the economy appears to be slowly recovering and contracted by $3.5 \%$ year on year (world bank, 2020). The Covid-19 pandemic has created an unprecedented shock to the world's economy. The International Monetary Fund (IMF) stated that the economic crisis arose partly due to several containment measures enacted by the government to halt the spread of the covid-19 virus. Lockdown strategies and restriction of mass activities affected the economy heavily, and this condition pushed the government to pass unprecedented fiscal, monetary, and other regulatory responses to maintain a household's disposable income (Long \& Ascent, 2020).

As the economy was plunged into recession, both financial and banking industries couldn't elude the downhill impact on their performance. On the other hand, drastic reductions in income and transaction were aggravating the impact of covid-19 on the industry. In general, the main challenge of the financial industry during the covid-19 pandemic is liquidity and the ratio of nonperforming financing (Wójcik \& Ioannou, 2020). A study using global data by (Demirgüç-Kunt et al.,

Corresponding author

Najwa Khairina, najwa.khairina@uinjkt.ac.id

DOI: 10.31098/ijebce.v2i1.722

Research Synergy Foundation 
International Journal of Entrepreneurship, Business and Creative Economy (IJEBCE), Vol. 2(1), 1-13 Bank's Digitalization and Financial Performance during Pandemic in Indonesia

Najwa Khairina

2020) shows that the adverse impact of covid-19 shocks on the bank was much more noticeable and had a long-lasting impact compared to non- bank financial institutions. These challenges need to be addressed by both the regulators and industry to avoid the downfall effect on the industry's performance which may lead to a deeper country's recession.

In the second quarter of 2020, Indonesia's Financial Services Authority (OJK) has issued several policies to restrain a more deteriorating effect of the covid-19 pandemic to the banking and finance industry. Some of the regulations are guidance for restructuring or rescheduling of financing, allowing banks to initiate programs as an incentive to the lender affected by covid-19 pandemic and simplify the clause of credit rating, which allows the bank to provide financing by considering mainly into lender's record of credit payment. These relaxations have allowed banks to withstand the adverse effect of pandemic-led recession on banks' performance.

On the other hand, the pandemic situations forced people to be socially distanced and discouraged them from going to public spaces unless it is very crucial. These situations led to drastic changes in interactions between people as well as drastic changes in business operations. As people are discouraged from making direct contact with others, communications have shifted to digital platforms and social media, while transactions between people and businesses are encouraged to be done through a cashless online payment. Optimizing the application of Information technology is a good strategy to support banks' business operations during the pandemic-led recession. The digitalization of banks' services is one of IT utilization to support banks' business. The Financial Service Authority (OJK) considers this as a strategy to provide excellent services to banks' customers, especially during current pandemic situations.

The adaptation process of financial digitization has been accelerated during the covid-19 pandemic. On the customers' side, covid-19 situations have forced them to do cashless transactions and avoid direct contact with others. Both central and local governments continuously persuade people to apply health protocols in all places and activities. These conditions encouraged people to do more transactions through digital platforms hence accelerating the adaptation process of banking and financial digitalization. On the other hand, from the business side, IT applications have been an issue in the past three decades. Both banking and financial industry players have realized that the advancement of technology should be utilized to improve industry performance, as well as provide better services to current customers.

Technology disruption in the financial and banking industry has changed business perspectives towards more customer-centered services (Pio et al., 2020). Banks and other financial institutions race to provide better services to the customer by creating digital platforms (Lee et al., 2020). Online transactions are considered as a more convenient, faster, and more personalized experience. In the last decades, both conventional and sharia banks in Indonesia have extended their services into digital banking. A survey conducted by PWC in 2018 shows that sharia banks perceive service digitalization as a part of the company's strategy. However, only $14 \%$ of sharia banks consider digital initiatives to enhance revenue growth; many still perceive that the digitalization process is a strategy to enhance customer experience (PWC, 2018). While some banks that utilize digital transformation to boost revenue growth only target an increase of $5 \%$ revenue from the banks' digital platform.

As technology advancement has changed the market dynamics, it becomes a necessity for the bank to grasp the competencies of digital technologies. The capabilities in the field of digital technologies are needed to compete better in the rapidly changing business environment (Romanova \& Kudinska, 2016). These needs become more relevant during the pandemic-led recession situation nowadays. Digital platforms may help banks to retain their customers, maintain the volume of transactions, and expand to new opportunities that may generate income (Vijayalakshmi R, 2020). In this paper, I focus on analyzing banking performance during the covid19 led recessions and how Banks' shifts to the digital channel are associated with better financial performance. The empirical estimates are shown to confirm that hypothesis. This paper is divided 
International Journal of Entrepreneurship, Business and Creative Economy (IJEBCE), Vol. 2(1), 1-13 Bank's Digitalization and Financial Performance during Pandemic in Indonesia

Najwa Khairina

into four sections; section 1 shows the introduction part, which describes the background of the study; section2 explains the previous research related to the topic; section 3 shows data description and methodology, and section 4 provides the descriptive analysis regression results and conclusions.

\section{LITERATURE REVIEW}

The literature review represents the theoretical core of an article. The purpose of a literature review is to "look again" what other researchers have done regarding a specific topic. A literature review is a means to an end, namely, to provide background to and serve as motivation for the objectives and hypotheses that guide one's own research. A good literature review should not merely provide a summary of previous relevant research; the researcher is also expected to critically evaluate, re-organize, and synthesize the work of others.

\section{RESEARCH METHOD}

The advancement of information technology has triggered the banking and financial industry to swift their business strategy by utilizing technology to create innovation in delivering their products and services. Digital banking innovators are focused on creating digital solutions bridging customers' problems to banks' specific services. This approach allows customers to have more choices and create more personalized banking transactions (Maiya, 2017). Two fundamental factors that drive banks to swift their business into digital platforms are online banking has proved to provide the cheapest service delivery, and by expanding services into digital channels, banks may downsize their branches and staff, and hence, customers may be benefitted from time and costsaving (Pikkarainen et al., 2004). As people move toward a digital lifestyle, it becomes inevitable for banks to adapt their business processes to digital life (Skinner, 2014).

To regulate the distribution and use of digital payment instruments, the government has enacted regulations of electronic money through Peraturan Bank of Indonesia No. 18/17/PBI/2016. This regulation provides a basis for an efficient electronic payment system and ensures transaction security (Tumpal Manik, 2019). Shifting banking services into digital platforms may provide wider services to customers as well as strengthen economic development. During the pandemic, the role of digital platforms has become more valuable since social distancing has given limitations for people's activity. Hence, digital services provide opportunities both for banks and customers to execute financial transactions remotely. A detailed explanation of digital transformation in the banking industry and its development during the pandemic is provided in the next sections.

\section{Digital Transformation in Indonesian Banking Industry}

The introduction of the digitalization process in the financial industry is defined as the growing use of information technology to manage a business in a more effective and efficient operational process (Henfridsson \& Bygstad, 2013). The terminology of financial technology or 'FinTech' is used to define the use of technology to run financial operations. FinTech marks the era of cloud and mobile banking with a personalized experience (Lee et al., 2020). In the developing countries where banks infrastructures are less deployed, digital banking channels offer an alternative to reach a wider market (Ivatury \& Mas, 2008). Digital banking channel provides efficiency and the ability to reach wider markets, and hence there is more reason to believe that digital banking may become the main channel for larger segments of the population. Digital Transformation in Indonesian Banking Industry started quite late compared to other Asian countries, such as Malaysia, Singapore, and South Korea. This is due to, among other things, the geographical conditions of Indonesia, which is an archipelago where digital literacy is not homogeneous, and people still have traditional beliefs and preferences for doing their banking in conventional physical branches. The first wave of digitalization in the Indonesian Banking Industry 
International Journal of Entrepreneurship, Business and Creative Economy (IJEBCE), Vol. 2(1), 1-13 Bank's Digitalization and Financial Performance during Pandemic in Indonesia

Najwa Khairina

started as early as the 1980s when automated teller machines (ATM) was introduced widely and became alternative solutions for doing banking transactions. However, until the late 1980s, some Indonesian banks still relied on semi- manual bookkeeping, and transactions were still dominated by cash. In 1990 when the need for interbank transactions increased, the clearing system of the government began to be strengthened. Some banks began to invest in technology, considering it as the solution to overcome the threat emerging from foreign bank business activities in Indonesia. Banks then began to improve the internal payment system, starting the new era of online transactions. In the 2000s, the development of banking technology became a necessity because banks that had survived the 1998 Indonesian economic crisis, where a number of banks had gone bankrupt, now had to compete with each other to fight over the customers who at that time had lost their trust in banks. In the following decade, the 2010s onward, the advantage of digital banking has become one of the important points that made banks survive the second economic crisis. This phase encouraged banks to invest more in digital projects, creating the second wave of digitalization in Indonesia. Several banks started to use various social media platforms to deliver, introduce and socialize various product features that are beneficial for their customers, such as open customer complaints service channels; and encourage interactive two-way communication so that customers feel more connected and respected. These strategies eliminated the old paradigm that banking services can only be accessed through conventional branches. The demands of banking digitalization were also strengthened by a shift in business ownership, which is currently dominated by millennial generations, who prefer the convenience of online and mobile transactions (Winasis et al., 2020)

To manage the digitalization process in a more effective way, banks need a good information technology infrastructure to support their performance. The digital infrastructures consist of, among others are, digital platform, information system as well as business and management system that has the ability to manage the digitalization process and generate a successful outcome.

\section{Development of Digital Services in Indonesia's Banking Industry during Covid-19 Pandemic}

The economic downturn impact of the covid-19 outbreak has made the global recession become inevitable. Within a few months of covid-19 outbreak cases, since it is officially announced in China, the disease quickly spread into countries and put the global population at life-threatening risk. The health crisis soon affects the global economy. The impact of the covid-19 pandemic on the global economy has surpassed the global financial crisis in 2008 only within a few months of theoutbreak (Hidayat et al., 2020). The pandemic situation has forced people to do work from home while children are experiencing online learning. Families whose breadwinners can work from home will tend to have stable incomes, but those who are daily workers have a high risk of losing their incomes, especially in the most affected industries such as tourism, construction, and property.

Domestic consumption has dropped significantly due to travel restrictions and social distancing rules imposed by the government. This has affected business operations and forced companies to lay off employees and/or daily workers. Many people lost their jobs or faced shrinking income; as the covid-19 outbreak kept spreading, employment opportunities were rare. Aside from growing unemployment, the covid-19 pandemic also affects micro and small-medium enterprises and has brought them to financial performance downfall. In this situation, both workers and businesses are struggling to pay their credit installments. This may lead to a financial downturn in banks and other financial institutions.

In response to the financial downturn due to the covid-19 pandemic, Indonesia's central bank (Bank of Indonesia) runs expansionary monetary policies to stimulate the economy (Sugandi, 2020). From January to the end of September 2020, the Bank of Indonesia had cut the reserve requirement ratio to $3.5 \%$ for both conventional and sharia banks. BI has also conducted a quantitative easing policy to inject liquidity in the economy, which from the beginning of the year until the end of September 2020 had amounted to IDR666 trillion (Sugandi, 2020). Meanwhile, 
International Journal of Entrepreneurship, Business and Creative Economy (IJEBCE), Vol. 2(1), 1-13 Bank's Digitalization and Financial Performance during Pandemic in Indonesia

Najwa Khairina

Indonesia's Financial Services Authority (OJK) issued a stimulus policy that includes credit restructuring for affected borrowers and leniency for banks in determining the quality assessment of financing to affected borrowers, as well as relaxation of periodic report submissions by financial institutions (Hidayat et al., 2020).

The covid-19 crisis will eventually raise non-performing financing in banks, and it will lead to jeopardy in banks' solvency. As both the central bank and financial service authority in Indonesia have provided regulations and stimulus packages to induce banks' performance, the crisis may bring some changes to banks' business operations. Digitalization may be accentuated since direct contact between people is discouraged, while cash transactions are also proved to be a transmission channel of virus infection (Allam, 2020). In addition, (Lyons et al., 2017) has suggested that financial digitalization is an innovative way to provide financial services efficiently while it will help banks to maintain their profitability.

The progressing development of Information Technology has shifted banking systems and transactions to a digital platform. Digital platforms have enabled banks to widen the type of services offered to customers, from the usual online transfer transactions to a current e-wallet payment system. In addition, digital banking may also stimulate the real economy and become an alternative solution to manage financial challenges during pandemics (Arner et al., 2020). (Pio et al., 2020) examine the dynamic movement of supply and demand of banking services as a result of technology disruption and pandemic- led recession. Financial digitalization has rolled across the globe, and the role of digital banking needs to be analyzed further to determine its contribution to a bank's performance.

The pandemic-led recession has indeed affected the global population. To hinder more harmful consequences of covid-19 spreading, many countries have applied social restriction regulations. This creates the need for the digitalization of many aspects of people's daily activities, from school and work to online payment for online grocery shopping. Going forward, Information Technology is seen as a solution for banks' business processes. Applying digitalization into banks' business processes allows for faster connectivity, creating alternative payment methods, increased financial inclusion, and reduced the cost of the transaction (Carletti et al., 2020).

According to Lipton et al. (2016), banking activity is mostly technological and mathematical in nature. That means most of the operational functions in banks can be transformed into forms of technology-based digital services. The banking system from the front end to the back end of the process can be done by utilizing technology and replacing the role of labor. Consequently, the role of technological advances and the implementation of digital banking is an opportunity for banks to improve competitiveness in the banking industry through increasing bank operational efficiency (Jamaruddin \& Markom, 2020).

In the Indonesian context, technological advances increase the number of digital devices users and changes in lifestyles leading to an increased market potential for digital banking and also the migration of conventional banking users to digital banking in Indonesia (PWC, 2018). Digital Banking products and services are one of the bank's strategies to increase and maintain its market share in the current era of digital competition. Based on digital banking surveys conducted by PWC in 2018, 66 percent of respondents stated that digital banking strategy is part of the company's strategy.

The fact that the current world changes to the era of technology, the internet, and digitalbased industry 4.0 have become a challenge for the banks to keep up with the speed of change, including Bank Central of Indonesia. For years, banks have had utter control over digital payment channels. However, since the entrance of e-commerce along with the associated e-wallet payment, the disruption in the payment channel is started, and banks are now competing with e-wallet providers. The convenience in payment and connection of e-wallets with other counterparts such as e-commerce and digital transportation companies has attracted customers to shift away from their money to e-money platforms. These conditions are threats for banks' business operations but also an opportunity to capture more markets in the future. Covid-19 pandemic will accelerate some 
International Journal of Entrepreneurship, Business and Creative Economy (IJEBCE), Vol. 2(1), 1-13 Bank's Digitalization and Financial Performance during Pandemic in Indonesia

Najwa Khairina

existing digital transformations in the banking industry. In the short run, the digitalization process may increase banks' competitiveness and may help banks to maintain financial performance during the downturn in consumer consumption in the pandemic period (Carletti et al., 2020).

Digital disruptions are a daunting challenge to both banks and regulators. Regulators should enact regulations to protect financial prudent and stability but at the same time should avoid the strict regulations that may create barriers to entry. The current pandemic-led crisis is a good challenge to test the flexibility of our financial system and regulation. A flexible environment will create a wide room for improvement and hence will support financial stability.

The empirical evidence found by (Sutrisno et al., 2020) shows that the pandemic had resulted in the decline of performance in most companies in Indonesia, especially banks. They found that several indicators of financial performance of sharia banks such as Return on Equity, Net Operating Margin, and Finance to Deposit Ratio have decreased significantly during the pandemic. To evaluate more on this issue in the overall banking industry, I collected some empirical data on banking performance before and during the pandemic. The section below will provide detailed descriptive and empirical analysis on this issue.

\section{FINDINGS AND DISCUSSION}

To analyze the effect of finance digitalization on to finance and banking industry, we use several survey results from The Financial Service Authority (OJK), Indonesia's Statistical Bureau, Bank of Indonesia (Indonesia, 2020), and APJII (Association of Internet Service Provider). This study uses descriptive and qualitative analysis to explore the impact of the digitalization process to finance dynamics in the financial and banking industry during the pandemic-led recession. In addition to the descriptive analysis, I use regression estimates to assess the association between a bank's financial performance and digital transactions empirically. The data for regression estimates are obtained from the Bank of Indonesia's banking statistics (Statistik Perbankan Indonesia).

Graph 1 below shows the total value of electronic transactions in Indonesia from 2015 to 2020. The data is obtained from the Bank of Indonesia's Series of Banking Statistics. From the below table, we can see the sharp increase in the total volume of digital transactions during the 20172018 period. However, the overall volume of transactions during 2019-2020 did not change substantially, and there is a small decrease during these periods. Thus, the overall data from 20152020 shows an increasing trend of digital transactions' volume.

Data shown in graph two is obtained from the Bank of Indonesia's Series of Banking Statistics. Graph 2 portrays the total nominal value of digital transactions during 2015-2020. Despite the decrease in volume during 2019-2020, the nominal value of digital transactions during this period shows a smooth increase. From this graph, we can also see an increasing trend in the total value of digital transactions. Hence, over the 2015-2020 period, both total volume and value of digital transactions show a growing trend.

Data shown in graph 3 is obtained from Bank of Indonesia's Series of Banking Statistics. This graph shows a decreasing number of ATM machines during the 2019-2020 period. This shows that Banks are shifting their services and reducing the conventional method of banking transactions, including ATM machines. Along with two previous data shown in graphs 1 and 2, we may get ideas that banks are shifting their services more into digital channels.

The changing preference for digital transactions has shifted banks to reduce the services of conventional banking such as ATM machines. In the period 2019-2020, the total number of ATM machines keeps declining. In addition, Graph 4 below shows the usage intensity of several channels of banking transactions during the period of 2010-2018. The data shown in graph 4 is obtained from Bank of Indonesia's Series of Banking Statistics. We can see clearly from graph 4 that the use of ATM machines is declining, and transactions are shifted to mobile banking. The trend moves toward the digitalization behavior of banks' customers. 
International Journal of Entrepreneurship, Business and Creative Economy (IJEBCE), Vol. 2(1), 1-13 Bank's Digitalization and Financial Performance during Pandemic in Indonesia

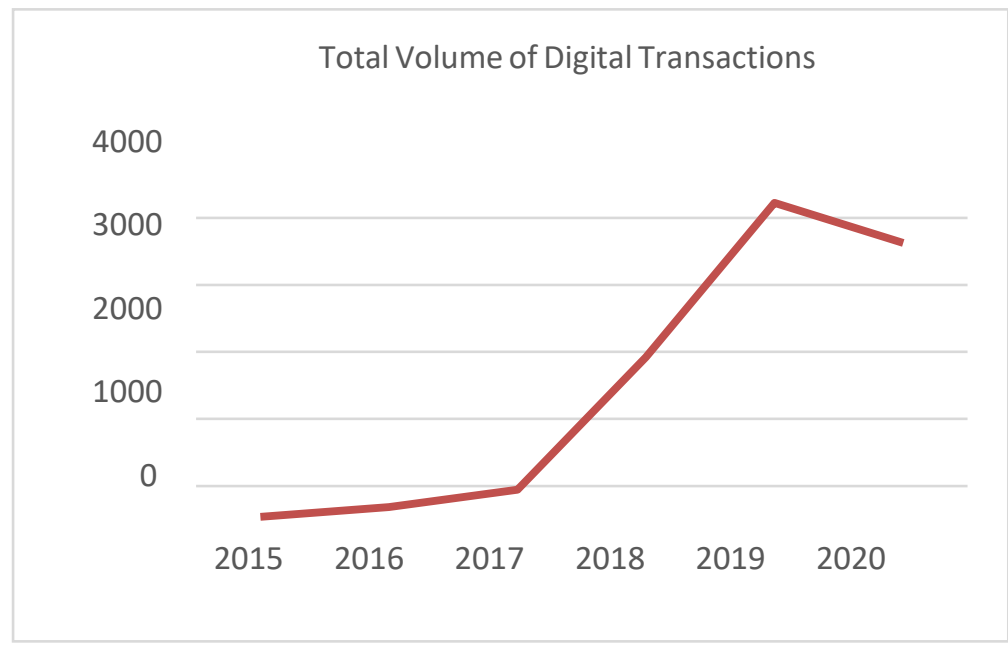

Graph 1. Total Volume of Digital Transactions Source: Bank of Indonesia

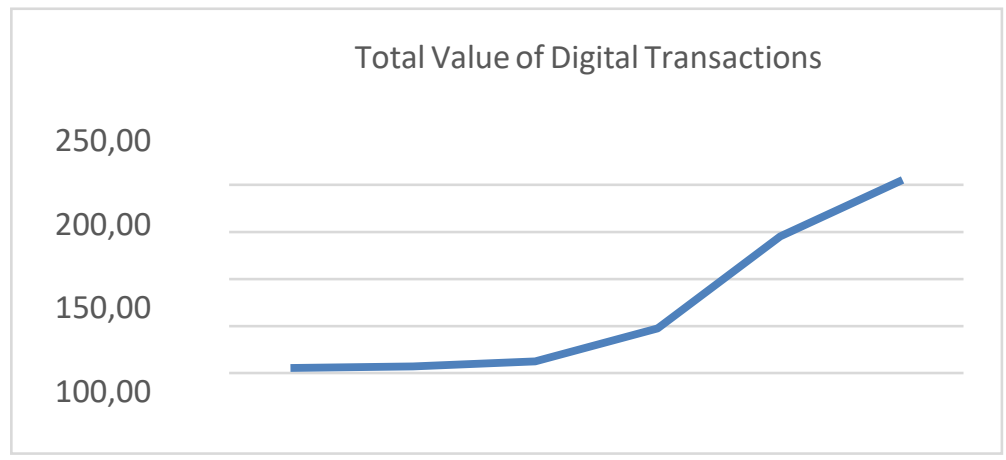

Graph 2. Total Value of Digital Transactions

Source: Bank of Indonesia

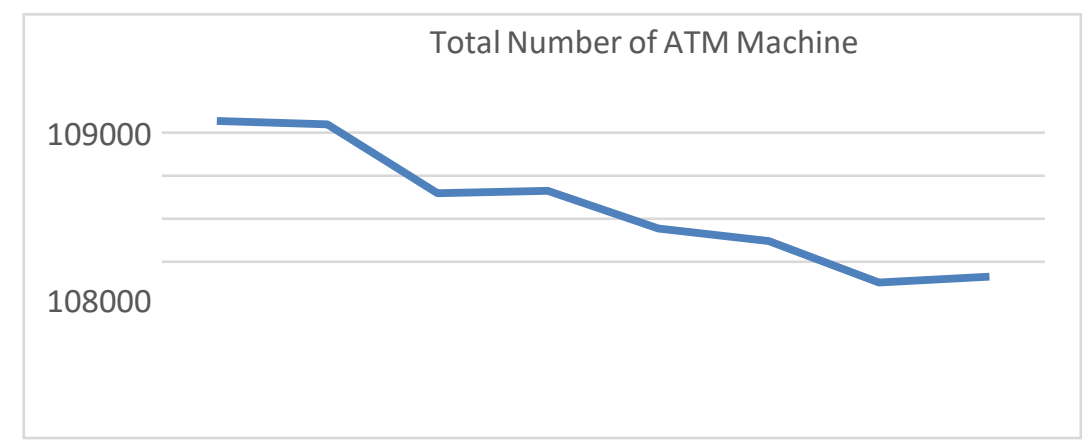

Graph 3. Total Number of ATM Machine Source: Bank of Indonesia

In 2010, banks transactions were mostly processed through ATMs or banks' branches. However, as we move to 2018, we can see that people have started to leave conventional methods of transactions through ATMs and bank branches and have started to use online banking more 
International Journal of Entrepreneurship, Business and Creative Economy (IJEBCE), Vol. 2(1), 1-13 Bank's Digitalization and Financial Performance during Pandemic in Indonesia

Najwa Khairina

often. Customer's changing preference to fintech applications is also mentioned by (Al Nawayseh, 2020); in his research, he found that during pandemic, customers have the higher perceived benefit of fintech application compared to the risk, and hence it drives them to have higher intention to use fintech application more often. As the general lifestyle has moved toward digitalization, banks should give more attention to increasing digital transactions. This should become more priority since our nation faces an unending and worse pandemic crisis.

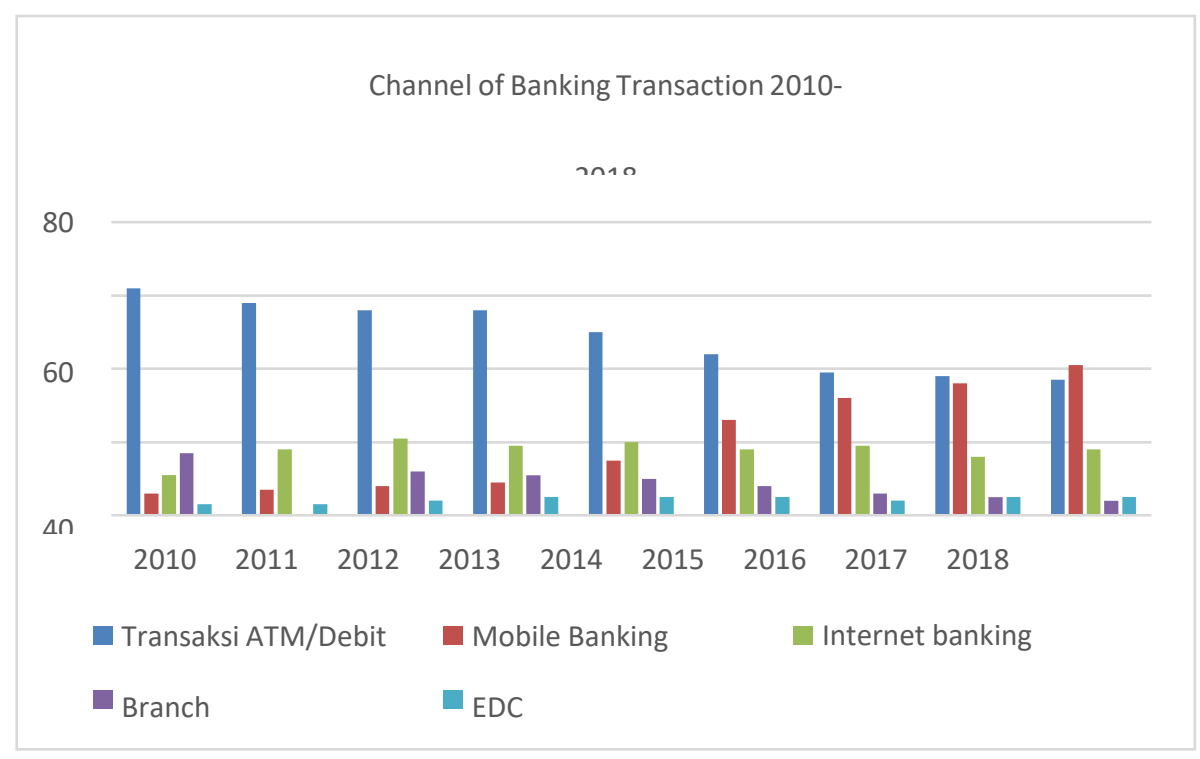

Graph. 4. Channel of Banking Transaction (2010-2018) Source: Bank of Indonesia

The urge for service digitalization is upsurging during the pandemic. Customers' preferences for epayment are rising. Graph 5 below shows several e-wallet payments during a pandemic; the most used e- wallets are Dana, e-money, and Shopee pay. Data shown in graph 5 is obtained from the Bank of Indonesia's Series of Banking Statistics. Data portrayed in graph 5 shows that customers are already familiar with e-wallets and use them for daily transactions. Banks should compete with these e-wallet platforms to provide digital services for daily transactions.

From all the graphs presented above, we may see the transitions of transactions to digital platforms. The upward trends show that over the years, consumers have shifted their preference toward digital platforms as the payment channel as well as for daily transactions. As the market moves forward to the digital era, banks have to respond by providing more digital services in order to capture a larger share of the market and enable them to compete with the new fintech companies. In addition to the data of digital transitions, the below graphs will show the bank's financial performance from 2019 to 2020 when the pandemic began. Data shown in graph 6 is obtained from Bursa Efek Indonesia, while Data shown in graph 7 is obtained from Bank of Indonesia's Series of Banking Statistics. 
International Journal of Entrepreneurship, Business and Creative Economy (IJEBCE), Vol. 2(1), 1-13 Bank's Digitalization and Financial Performance during Pandemic in Indonesia

Najwa Khairina

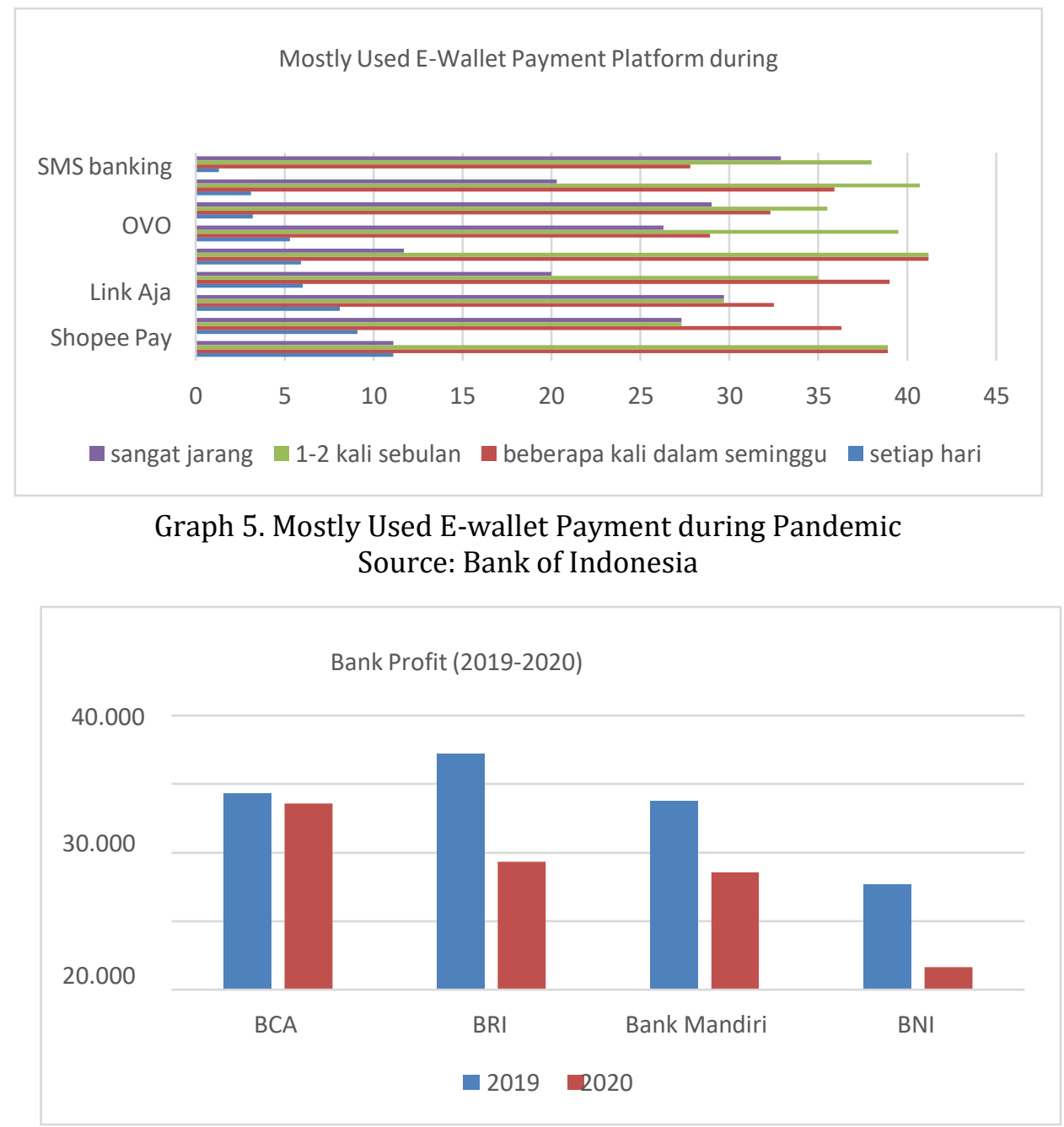

Graph 6. Banks Profit (2019-2020)

Source: Bursa Efek Indonesia

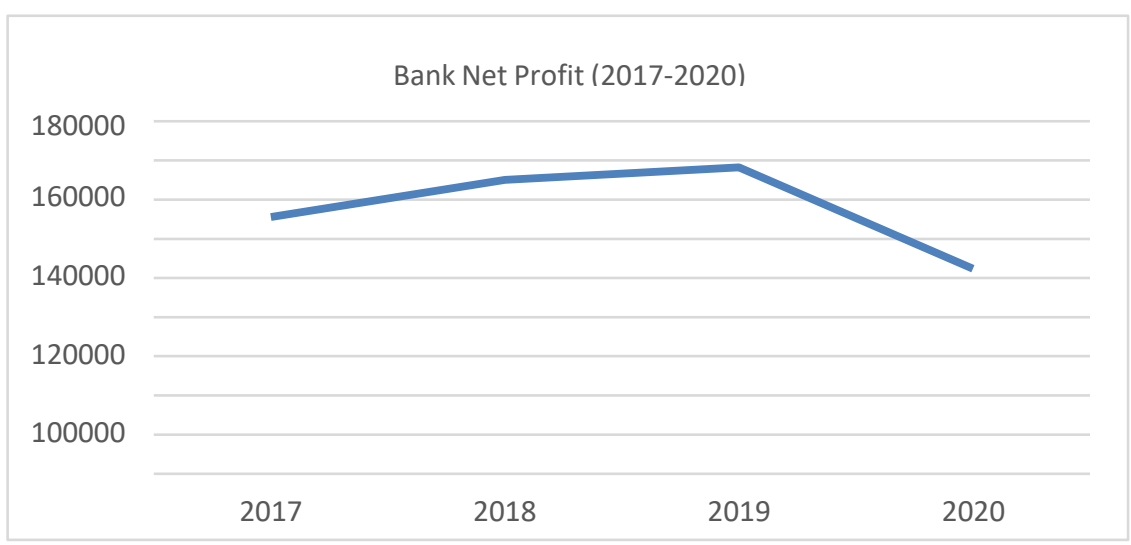

Graph 7. Aggregate Bank Net Profit (2017-2020)

Source: Bank of Indonesia 
International Journal of Entrepreneurship, Business and Creative Economy (IJEBCE), Vol. 2(1), 1-13 Bank's Digitalization and Financial Performance during Pandemic in Indonesia

Najwa Khairina

From both graphs 6 and 7, we can see the declining bank's profit during 2019-2020. Graph 6 shows the data of the four biggest banks in Indonesia, and it portrays how their profits decline substantially in the beginning phase of a pandemic. Graph 7 shows the aggregate data of bank's profit, and similar to the data shown in graph 6, the aggregate bank's net profit also shows a similar declining trend. The empirical data confirm my hypotheses that banks' financial performances are impacted heavily because of the drop in consumption as the covid-19 pandemic slows down our economy.

\section{EMPIRICAL ESTIMATES}

To further analyze the association of digital transactions with banks' performance, I use the OLS regression estimate. The model below is used to obtain the empirical estimates of the relationship between digital transactions, digital infrastructure, and banks' ROA as the proxy for banks' financial performance. The data for the empirical estimates of equation (1) is obtained from the bank of Indonesia in the banking statistics section. The data used in the regression is the observation of ROA, the volume of digital transactions, and digital infrastructure in monthly data from 2017-2020. I follow the paper by (Rianto et al., 2021)

$$
\begin{aligned}
& \mathrm{ROA}=\alpha_{0}+\beta_{1} * \text { volume }+\beta_{2} * \text { Digital Infrastructure }+\varepsilon \ldots \ldots . . .(1) \\
& \mathrm{ROA}=\alpha_{0}+\beta_{1} * \text { volume }+\beta_{2} * \text { Digital Infrastructure }+ \text { dpandemi }+\varepsilon
\end{aligned}
$$

ROA: return on asset as a proxy for bank's financial performance

Volume: total volume of digital transactions

Digital infrastructure: total number of digital infrastructure available at the market (such as the EDC payment machine, digital platforms, e-money card, etc.)

Dpandemi: dummy of the pandemic period ( 1 for the year during pandemic period, 0 otherwise)

Table 1 below shows the regression result of equation (1). The dependent variable in the model is ROA, while the independent variables are the total volume of digital transactions and digital infrastructure. The empirical result shows a significant F- statistic proving that the model shows the association between ROA, the volume of digital transactions, and digital infrastructure significantly. The r-square for this model is $26.75 \%$, even though it is not high enough, which is a good indication of relations between dependent and independent variables in the model.

\begin{tabular}{|c|c|c|c|}
\hline \multicolumn{4}{|c|}{ Dependent Variable: ROA } \\
\hline Var. Independent & Coefficient & t-stat & Prob \\
\hline Constant & 145.5292 & 15.9396 & $0.0000^{* * *}$ \\
\hline Volume & 0.000000049 & 2.926464 & $0.0054^{* * *}$ \\
\hline $\begin{array}{c}\text { Digital } \\
\text { Infrastructure }\end{array}$ & 0.0000242 & 1.75 & $0.0863^{*}$ \\
\hline \multicolumn{2}{|l|}{ R-Square } & \multicolumn{2}{|l|}{0.2675} \\
\hline Prob (F) & & 0.000907 & \\
\hline
\end{tabular}

Table 1. Regression Output for equation 1

${ }^{* * *}$ significant at $1 \%,{ }^{* *}$ significant at $5 \%,{ }^{*}$ significant at $10 \%$

Further, both of the independent variables show significant probability verifying that both are empirically associated with ROA as the proxy for a bank's financial performance. However, the very small number of coefficients for both volume and digital infrastructure may imply that the associations are very trivial. However, the association may improve if other related variables are added to the model and the number of observations period is extended. The coefficient for the 
International Journal of Entrepreneurship, Business and Creative Economy (IJEBCE), Vol. 2(1), 1-13 Bank's Digitalization and Financial Performance during Pandemic in Indonesia

Najwa Khairina

volume of digital transactions implies that as the volume of digital transactions increases by 1 point, the ROA will increase by 0.00000049 , or in other words, if the volume of digital transactions increases by 1 million, ROA will increase by 0.49 points. The coefficient of digital infrastructure implies that if the number of digital infrastructures available at the market raise by 1 point, ROA will increase by 0.0000242 , or in other words, if the number of digital infrastructures rises by 100.000 points, ROA will increase by 2.42 points.

Table 2. Regression Output for equation 2

\begin{tabular}{|c|c|c|c|}
\hline \multicolumn{4}{|c|}{ Dependent Variable: $\log (\mathrm{ROA})$} \\
\hline Independent & Coefficient & t-stat & Prob \\
\hline Constant & 3.786372 & 11.65621 & $0.0000^{* * *}$ \\
\hline Log(volume) & 0.103206 & 7.975511 & $0.0000^{* * *}$ \\
\hline $\begin{array}{l}\text { Log(digital } \\
\text { infrastructure })\end{array}$ & -0.043102 & -1.169671 & 0.2484 \\
\hline dpandemi & -0.177957 & -2.585991 & $0.0131^{* *}$ \\
\hline R-Square & & 0.548349 & \\
\hline Prob (F) & & 0.000000 & \\
\hline
\end{tabular}

${ }^{* * *}$ significant at $1 \%,{ }^{* *}$ significant at $5 \%,{ }^{*}$ significant at $10 \%$

Table 2 above shows the empirical estimates for equation (2). The result shows that the pandemic situation decreased ROA by -0.177 points. This proves the hypothesis that pandemic has brought financial difficulties and performance downturn for the banking industry. In addition, the $\log$ (volume) variable shows positive and significant results, confirming that digital transactions may help banking industries maintain their financial performances.

\section{CONCLUSION}

The descriptive analysis of the data shows that banks' financial performance has declined sharply during 2020. On the other hand, the consumers' preference for transactions channels has shifted to digital platforms. The intensity of use of ATM and teller transaction as a convenient means to deal with daily transactions are decreasing. Consumer preferences are shifting to digital payments. The pandemic situation that requires people to be socially distanced also forces the banking industry to provide more operational services to consumers to retain operational profit from daily transactions. Both conditions have led to the acceleration of digital transformation in the banking industry.

To analyze more on the issue of association between a bank's financial performance and digital transactions, I use regression estimates of ROA as the proxy of bank's financial performance and volume of digital transactions and digital infrastructure available at the market. The empirical evidence shows that both volumes of digital transactions and digital infrastructure have a positive association with ROA. The first regression estimates imply that an increase in the volume of digital transactions by 1 million will raise ROA by 0.49 points, while an increase in digital infrastructure by 100.000 will increase ROA by 2.42 points. In addition, I regress equation 2 to incorporate the dummy variable of the pandemic period; I find that pandemic condition has indeed worsened the banking industry's financial performance and contributed to the decrease of banks' ROA by 0.177 points. On the other hand, the volume of digital transactions is associated with a $10 \%$ increase in Banks' ROA. The empirical estimates imply that the digital channel has a promising ability to maintain banks' performance during the downturn in the overall economy.

Limitations on this research are mainly due to the limitation of the data, which is only available on a monthly basis from 2017-to 2020. A time span to analyze the pandemic situation is only during the year 2020. A longer period of time is needed to capture the effect of a pandemic on the overall 
International Journal of Entrepreneurship, Business and Creative Economy (IJEBCE), Vol. 2(1), 1-13 Bank's Digitalization and Financial Performance during Pandemic in Indonesia

Najwa Khairina

bank's performance. In addition, a better analysis to compare before and after conditions should be done by Difference in Difference (DiD) regression; however, in this paper, I can't proceed with DiD regression due to the data limitations. Further research on this topic should be better executed with longer data and a better empirical strategy.

\section{REFERENCES}

Al Nawayseh, M. K. (2020). Fintech in COVID-19 and beyond: What factors are affecting customers' choice of fintech applications? Journal of Open Innovation: Technology, Market, and Complexity, 6(4), 1- 15. https://doi.org/10.3390/joitmc6040153

Allam, Z. (2020). The Forceful Reevaluation of Cash-Based Transactions by COVID-19 and Its Opportunities to Transition to Cashless Systems in Digital Urban Networks. Surveying the Covid-19 Pandemic and Its Implications, 107-117. https://doi.org/10.1016/b978-0-12824313-8.00008-5

Arner, D. W., Barberis, J. N., Walker, J., Buckley, R. P., \& Zetzsche, D. A. (2020). Digital Finance \&amp; Crisis. SSRN Electronic Journal. https://doi.org/10.2139/ssrn.3558889

Carletti, E., Claessens, S., Fatás, A., \& Vives, X. (2020). The Bank Business Model in the Post-Covid19 World. In IESE Business School University of navarra. http://de.wikipedia.org/wiki/Model_in_the_Loop

Craven, M., Singhal, S., \& Wilson, M. (2020). COVID-19 : Briefing note, April 13, 2020. McKinsey \& Company, April, 9.

Demirgüç-Kunt, A., Morales, A., \& Ruiz Ortega, C. (2020). Banking Sector Performance During the COVID-19 Crisis. SSRN Electronic Journal, August. https://doi.org/10.2139/ssrn.3689789

Henfridsson, O., \& Bygstad, B. (2013). THE GENERATIVE MECHANISMS OF DIGITAL

INFRASTRUCTURE Bendik Bygstad Norwegian School of IT \& University of Oslo THE GENERATIVE MECHANISMS OF DIGITAL INFRASTRUCTURE. MIS Quarterly, 37(3), 907-931.

Hidayat, S. E., Farooq, M. O., Nasution, A., \& Sari, C. A. (2020). COVID-19 And Its Impacts On The Islamic Financial Industry In The OIC Countries. In The Impact Of COVID-19 Outbreak On The Islamic Finance In The OIC Countries.

Indonesia, B. (2020). Statistik Sistem Pembayaran Jumlah Uang Elektronik Beredar.

Ivatury, G., \& Mas, I. (2008). The early experience with branchless banking. CGAP Focus Note, 46. Jamaruddin, W. N., \& Markom, R. (2020). the Application of Fintech in the Operation of Islamic

Banking. Syariah and Law in Facing COVID-19: The Way Forward, 3(1), 31-43. https://insla.usim.edu.my/index.php/eproceeding/article/view/16

Lee, J., Wewege, L., \& Thomsett, M. C. (2020). Disruptions and Digital Banking Trends. Journal of Applied Finance $\quad \& \quad$ Banking, 10(6), 1792-6599. https://www.researchgate.net/publication/343050625

Long, A., \& Ascent, D. (2020). World Economic Outlook. International Monetary Fund.

Lyons, A. C., Grable, J. E., \& Zeng, T. (2017). Infrastructure, urbanization, and demand for bank and non-bank loans of households in the People's Republic of China.

Maiya, R. (2017). How to be a truly digital bank. Journal of Digital Banking, 1(4), 338-348. https://www.henrystewartpublications.com/sites/default/files/Maiya_JDB_V1_4.pdf

Pikkarainen, T., Pikkarainen, K., Karjaluoto, H., \& Pahnila, S. (2004). Consumer acceptance of online 
International Journal of Entrepreneurship, Business and Creative Economy (IJEBCE), Vol. 2(1), 1-13 Bank's Digitalization and Financial Performance during Pandemic in Indonesia

Najwa Khairina

banking: An extension of the technology acceptance model. Internet Research, 14(3), 224235. https://doi.org/10.1108/10662240410542652

Pio, L., Cavaliere, L., \& Bhatia, S. (2020). Digital Technologies' Implementation Within Financial and Banking System During Socio Distancing Restrictions - Back To the. 11(6), 307-315. https://doi.org/10.34218/IJARET.11.6.2020.027

PWC.(2018). Digital Banking in Indonesia 2018. PwC Survey, July, 1-48. https://www.pwc.com/id/en/publications/assets/financialservices/digitalbanking-survey-2018- pwcid.pdf

Romanova, I., \& Kudinska, M. (2016). Banking and fintech: A challenge or opportunity? Contemporary Studies in Economic and Financial Analysis, 98, 21-35. https://doi.org/10.1108/S1569- 375920160000098002

Skinner, C. (2014). Digital Bank: Strategies to launch or become a digital bank. Marshall Cavendish International Asia Pte Ltd.

Sugandi, E. A. (2020). AMID THE COVID-19 PANDEMIC Asian Development Bank Institute. 1198. Sutrisno, S., Panuntun, B., \& Adristi, F. I. (2020). The Effect of Covid-19 Pandemic on the

Performance of Islamic Bank in Indonesia. Equity, 23(2), 125. https://doi.org/10.34209/equ.v23i2.2245 Trianto, B., Yuliaty, T., \& Sabiu, T. T. (2021). Jurnal Ekonomi dan Keuangan Islam. 7(2), 105-122. Tumpal Manik. (2019). Analisis Pengaruh Transaksi Digitalisasi Uang Elektronik Terhadap

Cashless Society Dan Infrastruktur Uang Elektronik Sebagai Variabel Pemodarasi. Jurnal Ilmiah Akuntansi Dan Finansial Indonesia, 2(2), 27-40. https://doi.org/10.31629/jiafi.v2i2.1714

Vijayalakshmi R. (2020). GAP Interdisciplinarities A Global Journal Of Interdisciplinary Studies A STUDY ON IMPACT OF COVID 19 IN BANKING SERVICE SECTOR AND CHANGES IN CUSTOMER

PERCEPTION. 875(Iv), 74-77. https://www.gapinterdisciplinarities.org/

Winasis, S., Riyanto, S., \& Ariyanto, E. (2020). Digital Transformation in Indonesian Banking Industry: Impact on Employee Engagement. International Journal of Innovation, Creativity and Change, Pending for Published March, 2020.

Wójcik, D., \& Ioannou, S. (2020). COVID-19 and Finance: Market Developments So Far and Potential Impacts on the Financial Sector and Centres. Tijdschrift Voor Economische En Sociale Geografie, 111(3), 387-400. https://doi.org/10.1111/tesg.12434 